\title{
Preface: Field investigation of ocean acidification effects in northwest European seas
}

\author{
T. Tyrrell ${ }^{1}$ and E. P. Achterberg ${ }^{1,2}$ \\ ${ }^{1}$ Ocean and Earth Science, National Oceanography Centre Southampton, University of Southampton, Southampton, UK \\ ${ }^{2}$ GEOMAR Helmholtz Centre for Ocean Research, 24148 Kiel, Germany
}

Correspondence to: T. Tyrrell (toby.tyrrell@ soton.ac.uk)

The $\mathrm{pH}$ of the ocean is being lowered by its uptake of anthropogenic atmospheric carbon dioxide $\left(\mathrm{CO}_{2}\right)$, produced as a result of combustion of fossil fuels and land use changes. This acidification is especially pronounced in the surface ocean, where the loadings of anthropogenic $\mathrm{CO}_{2}$ are greatest because of the direct contact with the atmosphere. Much of the work to date has tried to elucidate the biological and biogeochemical consequences of this surface ocean acidification by carrying out studies in the laboratory. This paper gives an overview of work carried out on a cruise in northwest European shelf seas in June and July 2011. The objectives of the cruise were to study ocean acidification impacts by collecting observations from the natural environment across carbonate chemistry gradients, and by carrying out short-term (96h) bioassay $\mathrm{CO}_{2}$ perturbation experiments on natural populations. In both cases the aim was to enhance our understanding of the impacts of ocean acidification through studies of the natural world with as little artificiality as possible. Here we give an overview of the conditions encountered during this cruise and give a brief introduction to the individual studies that were carried out and whose results are presented in the separate papers in this special issue.

\section{Background}

At the time of writing, efforts to restrict emissions of $\mathrm{CO}_{2}$ to the atmosphere (in order to limit global warming and ocean acidification) have not been successful, and concentrations of atmospheric $\mathrm{CO}_{2}$ are following or even exceeding the higherend scenarios of earlier ranges of projections (Leggett et al., 1992). Atmospheric $\mathrm{CO}_{2}$ is currently about $40 \%$ higher than before the industrial revolution (having risen from 280 to $400 \mathrm{ppmv}$ ) as a result of large-scale anthropogenic emissions, and surface ocean $\mathrm{pH}_{\mathrm{T}}(\mathrm{pH}$ on the total $\mathrm{pH}$ scale) is currently about 0.1 units lower than pre-industrial levels (having fallen from an average of 8.2-8.1). It is projected that, unless $\mathrm{CO}_{2}$ emissions are successfully curtailed in the future, surface ocean $\mathrm{pH}_{\mathrm{T}}$ will decrease by a further 0.3 units by the end of this century, to an average of about 7.8 in the year 2100 (Gattuso et al., 2014; Representative Concentration Pathway 8.5), with further reductions to about 7.5 possible in succeeding centuries (Caldeira and Wickett, 2003). $\mathrm{A} \mathrm{pH}_{\mathrm{T}}$ reduction by 0.4 units corresponds to an increase of $130 \%$, i.e. more than a doubling, in the hydrogen ion concentration. While these changes to surface ocean $\mathrm{pH}_{\mathrm{T}}$ will not make surface seawater technically acidic (because $\mathrm{pH}_{\mathrm{T}}$ will not drop below 7.0, seawater will remain alkaline), the rate of change of ocean $\mathrm{pH}$ has probably not been experienced by marine ecosystems for tens of millions of years. There is now a large international research effort underway to attempt to understand the ecosystem and biogeochemical consequences of these ongoing changes in $\mathrm{pH}$.

In 2009, several UK organisations (see Acknowledgements) agreed to fund a large programme to investigate the impacts of ocean acidification, of which a major component is a consortium studying the impacts of ocean acidification on the surface ocean in particular. The aim of this surface ocean consortium, the first results of which are reported in this special issue, is to examine the impacts of the continuing atmospheric $\mathrm{CO}_{2}$ rise on (1) marine organisms and ecosystems, (2) the cycling of carbon and nutrients in the sea, and (3) how the ocean interacts with the atmosphere to influence climate. The consortium as a whole has therefore examined a range of different possible impacts, including both the most likely and also the potentially most important (even if less likely) impacts of ocean acidification.

Our understanding of the impacts of ocean acidification is mainly based on results of laboratory studies. This was especially true at the time that the consortium's work was planned, and remains true today. While laboratory 
experiments are advantageous in the sense of tight control over conditions and a high degree of replication, it is not always straightforward to know whether their results are applicable to the situation in the real world. The environmental conditions in laboratory experiments are typically not very realistic, organisms are grown in isolation (monocultures) rather than interacting actively with the surrounding ecosystem as occurs naturally, and timescales do not normally allow for assessment of the possibility of evolutionary adaptation to the imposed stressor (although see Collins and Bell, 2006; Lohbeck et al., 2012). An example of the difficulty in extrapolating from laboratory experiments to the real world comes from studies of the nitrogen fixer Trichodesmium. Early work on this important nitrogen-fixing organism found that the rate at which it fixes nitrogen is strongly stimulated by enhanced $\mathrm{CO}_{2}$ levels. Several studies all showed the same result (Barcelos e Ramos et al., 2007; Hutchins et al., 2007; Levitan et al., 2007; Kranz et al., 2009; Lomas et al., 2012). It appeared that a solid result had been obtained and that we were progressing towards a robust and accurate understanding of the effect of ocean acidification on nitrogen fixation. However, the earlier studies had all been conducted at unrealistically high nutrient concentrations. Experiments at sea, on natural plankton communities incubated at in situ nutrient concentrations, did not observe the effect (Law et al., 2012). A later laboratory experiment (Shi et al., 2012), carried out this time under more realistic (limiting) iron concentrations, obtained the opposite result, with higher $\mathrm{CO}_{2}$ leading to reduced nitrogen fixation. Care is therefore needed in extrapolating from laboratory results to the real world.

Another important approach to understanding ocean acidification impacts has been the use of mesocosm studies (e.g. Riebesell et al., 2010), a number of which have been carried out, mainly in European waters. These are much more realistic than most laboratory experiments and have provided valuable information towards our understanding of ocean acidification impacts. As with all other approaches, there are, however, limitations: they have been carried out mainly in coastal areas rather than the open sea, and nutrient concentrations were again not at natural levels for all experiments because nutrients were added to stimulate growth in the earlier experiments.

The sea surface consortium of the UK programme looked to provide an alternative and complementary approach to previous work, trying to adopt a more natural and realistic approach by studying the surface ocean in situ. Firstly, observational data were analysed to investigate how organisms, ecosystems and processes vary between places across natural carbonate chemistry gradients. Assuming that resident organisms are evolutionarily adapted to local conditions, this comparison of observational data should give insights into the likely effects of ocean acidification as it occurs over centuries, during which time natural selection and adaptation may modify plankton in response to the ocean acidification. A second approach was to conduct short-term bioassay $\mathrm{CO}_{2}$

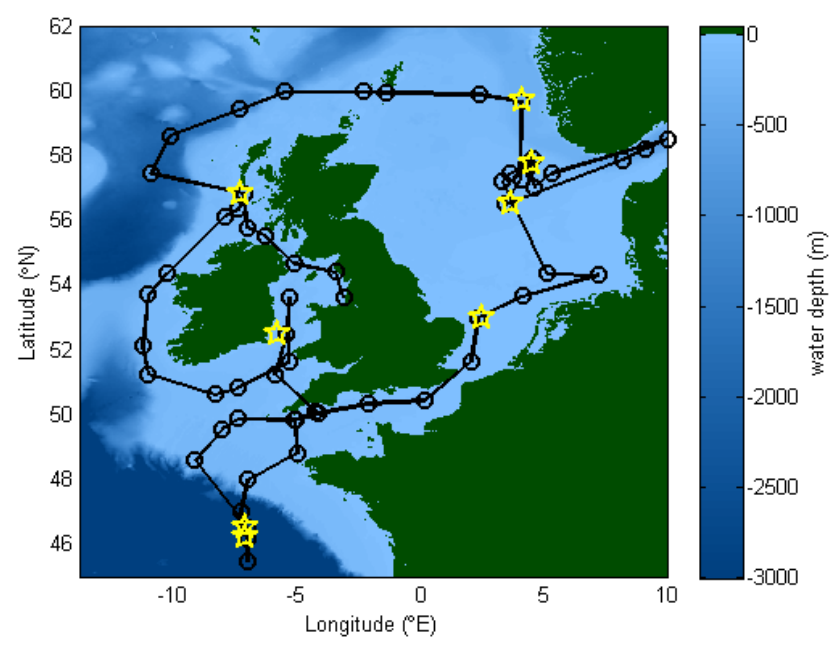

Figure 1. Cruise track superimposed on a map of the bathymetry of the study area (from the ETOPO5 data set). Locations of CTD stations are shown with black circles. Locations of eight bioassay experiments are shown with yellow stars.

perturbation experiments (see also Law et al., 2012; Tatters et al., 2013) using natural seawater collected from the surface of the sea and brought into a controlled laboratory on the deck of the research ship. This natural unfiltered seawater was subjected to various levels of $\mathrm{CO}_{2}$ that may occur in the future, and the responses were measured. This large experiment examined the effects of changing $\mathrm{CO}_{2}$ levels on realworld samples collected out at sea.

Here we report results from studies on the first of three cruises carried out by the sea surface consortium. This cruise took place in June and July 2011 in northwest European shelf seas (Fig. 1).

Shelf seas form the interface between the land and open ocean, contain important ecosystems and play an important role in the global biogeochemical cycles of carbon and nutrients. Additional physical and biogeochemical processes operate in shelf seas that are much less important in the open ocean. The shelf seas feature enhanced nutrient inputs from rivers and a greater importance of atmospheric and benthic elemental exchanges due to their shallow depths $(<200 \mathrm{~m})$. They experience pronounced tidal mixing, as well as, in many places, seasonal summer stratification due to density changes as a result of solar heating (Simpson and Sharples, 2012). Shelf seas comprise only ca. $5 \%$ of the global ocean area, but are 3-4 times more productive than typical ocean systems and support 15-20\% of global primary productivity (Simpson and Sharples, 2012). Shelf seas therefore play a key role in the air-sea fluxes of greenhouse gases, with ca. $29 \%$ of the global air-sea $\mathrm{CO}_{2}$ flux occurring in these systems (Chen and Borges, 2009). The biological carbon and solubility pumps provide a net uptake of $\mathrm{CO}_{2}$ by shelf seas with a subsequent export to the deep ocean (Thomas et al., 2004). Shelf seas are considered a source of $\mathrm{N}_{2} \mathrm{O}$ through 
nitrification and denitrification, but this flux is poorly quantified on a spatial and temporal basis (Bange, 2006). Shelf seas provide important ecosystem services, supporting $90 \%$ of global fish catches (Pauly et al., 2002) and offering a multitude of recreational opportunities.

The research cruise was conducted in the period 6 June9 July 2011 on RRS Discovery (cruise D366). The cruise track followed during D366 is shown in Fig. 1, and covered a distance of 4730 nautical miles. A total of 75 CTD casts were conducted at 69 stations occupied in the period between 6 June and 7 July 2011 in European waters. We typically occupied two stations per day, one pre-dawn and one close to midday. In addition to the observational study, we conducted eight biological $\mathrm{CO}_{2}$ incubation experiments using surface waters incubated at target $p \mathrm{CO}_{2}$ levels of ambient, 550,750 and $1000 \mu \mathrm{atm}$. The incubations were conducted in a purpose-built laboratory container, featuring light and temperature control.

\section{Environmental conditions during the cruise}

The route taken by the cruise was chosen in order to sample across a high degree of environmental and biological variability, including areas with different $\mathrm{pH}_{\mathrm{T}}$ and carbonate chemistry. In particular, two areas along the route (the southern North Sea and the Irish Sea) are known to have a fully mixed water column throughout the year, including the summer, in contrast to the rest of the route (including the northern North Sea, the Celtic Sea, the western English Channel and the Bay of Biscay), where the water column becomes stratified during the summer months (Simpson and Sharples, 2012). Vertical profiles of temperature and salinity collected during CTD casts confirmed this general picture (two example profiles are shown in Fig. 2). The background to Fig. 1 shows the bathymetry and the position of the shelf break and slope dividing the continental shelf from the deep ocean. The water depth of northwest European shelf seas is typically shallower than $250 \mathrm{~m}$, with the exception of the Norwegian Trench, which extends to $700 \mathrm{~m}$ (Pingree and Griffiths, 1978). The depths of the English Channel and Celtic Sea increase towards the shelf edge with the Atlantic Ocean. The depth of the North Sea increases from ca. $50 \mathrm{~m}$ in the southern parts to ca. $150 \mathrm{~m}$ in the north. The Irish Sea is typically less than $80 \mathrm{~m}$ deep in the eastern parts, with a deeper (up to $250 \mathrm{~m}$ ) north-south trough. The average temperature of the surface waters during the month of June 2011, as measured by satellite (Fig. 3), was $13.2^{\circ} \mathrm{C}$.

Our expectation, based on previous work (Thomas et al., 2004), was that the distinction between stratified and nonstratified waters along the route would lead to a variety of carbonate chemistry conditions and a decoupling of the normally strong correlation between temperature and carbonate chemistry. Analysis of our careful measurements of multiple parameters of the carbonate chemistry system (see Ribas-

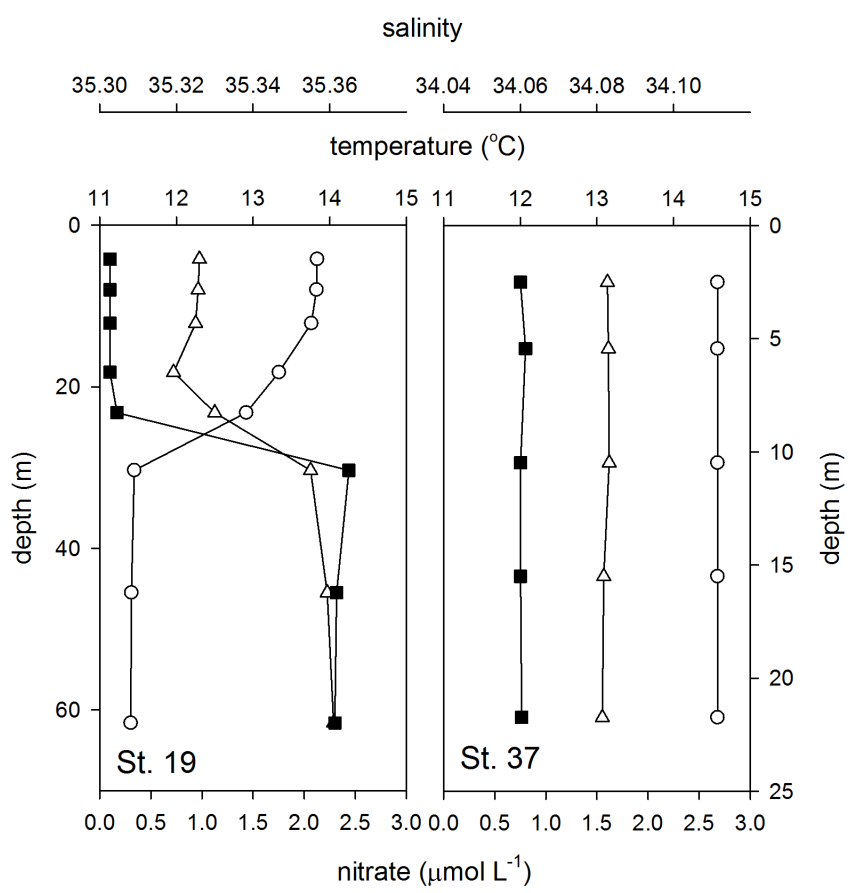

Figure 2. Two example depth profiles of temperature, salinity and nitrate: (a) from station 19 in the western English Channel (15 June $\left.2011 ; 50.029^{\circ} \mathrm{N}, 4.3795^{\circ} \mathrm{W}\right)$ with stratified water column, and (b) from station 37 in the southern North Sea (26 June 2011; $52.995^{\circ} \mathrm{N}, 2.501^{\circ} \mathrm{E}$ ) with a fully mixed water column. Open circles: temperature; open triangles: salinity; black squares: nitrate.

Ribas et al., 2014) confirmed both that the carbonate chemistry was measured accurately and that there was a considerable variation in surface water carbonate chemistry along the route (e.g. $\mathrm{pH}_{\mathrm{T}}$ between 8.03 and 8.20 , saturation state for aragonite between 2.0 and 3.0, and saturation state for calcite between 3.2 and 4.7), as expected.

Surface water nutrient concentrations were low $\left(\left[\mathrm{NO}_{3}\right]<0.3 \mu \mathrm{mol} \mathrm{L}-1, \quad\left[\mathrm{PO}_{4}\right] \approx 0.2 \mu \mathrm{mol} \mathrm{L}^{-1} \quad\right.$ and $\left[\mathrm{SiO}_{4}\right] \approx 0.4 \mu \mathrm{mol} \mathrm{L}^{-1}$ ) in the stratified shelf waters (Celtic Sea, western English Channel and North Sea). Sites at the shelf break had higher nutrient concentrations $\left(\left[\mathrm{NO}_{3}\right]=1.1-6.2 \mu \mathrm{mol} \mathrm{L}^{-1}, \quad\left[\mathrm{PO}_{4}\right]=0.1-0.4 \mu \mathrm{mol} \mathrm{L}^{-1}\right.$ and $\left[\mathrm{SiO}_{4}\right]=0.1-0.4 \mu \mathrm{mol} \mathrm{L}^{-1}$ ) compared to the stratified shelf sites. Open ocean waters of the Bay of Biscay showed $\left[\mathrm{NO}_{3}\right]=0.3-1.1 \mu \mathrm{mol} \mathrm{L}-1,\left[\mathrm{PO}_{4}\right]<0.1 \mu \mathrm{mol} \mathrm{L}{ }^{-1}$ and $\left[\mathrm{SiO}_{4}\right]=0.7-1.3 \mu \mathrm{mol} \mathrm{L}-1$. The mixed waters had quite different nutrient concentrations: the Irish Sea was $\quad\left[\mathrm{NO}_{3}\right]=0.3 \mu \mathrm{mol} \mathrm{L}-1, \quad\left[\mathrm{PO}_{4}\right]=0.14 \mu \mathrm{mol} \mathrm{L}^{-1}$ and $\left[\mathrm{SiO}_{4}\right]=0.45 \mu \mathrm{mol} \mathrm{L}^{-1}$; the southern North Sea was $\quad\left[\mathrm{NO}_{3}\right]=0.7 \mu \mathrm{mol} \mathrm{L}^{-1}, \quad\left[\mathrm{PO}_{4}\right]=0.1 \mu \mathrm{mol} \mathrm{L}{ }^{-1}$ and $\left[\mathrm{SiO}_{4}\right]=0.7 \mu \mathrm{mol} \mathrm{L}^{-1}$; and off Heligoland was $\left[\mathrm{NO}_{3}\right]=4.3 \mu \mathrm{mol} \mathrm{L}^{-1}, \quad\left[\mathrm{PO}_{4}\right]=0.1 \mu \mathrm{mol} \mathrm{L}^{-1} \quad$ and $\left[\mathrm{SiO}_{4}\right]=3.4 \mu \mathrm{mol} \mathrm{L}{ }^{-1}$. Average mixed layer irradiance (determined by integrating continuous measurements of downwards irradiance down to the depth of the 


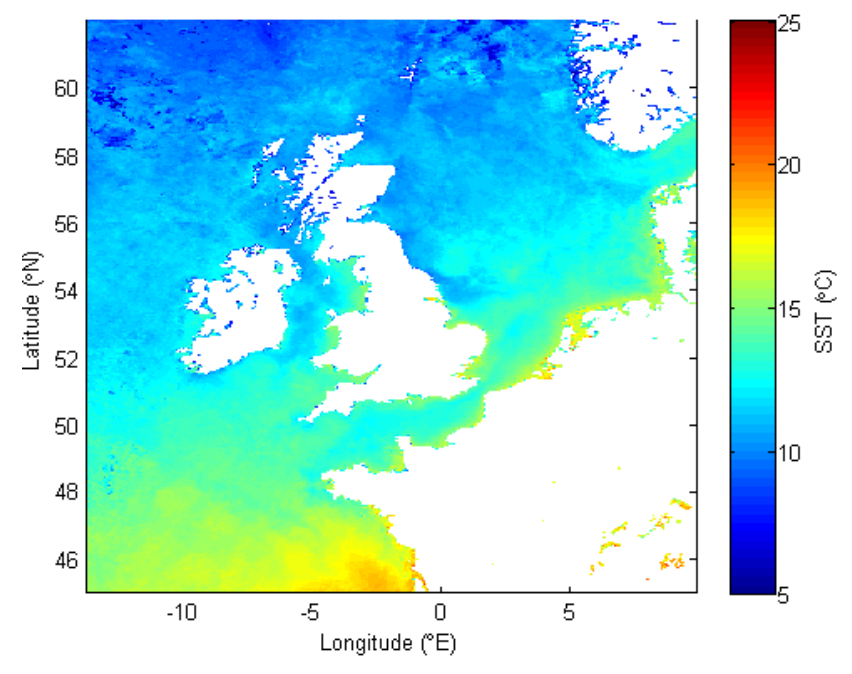

Figure 3. Aqua MODIS monthly composite image of sea surface temperature (SST) across the study area in June 2011. SST at $4.63 \mathrm{~km}$ resolution is determined from mid-infrared radiation measured during night-time passes.

bottom of the surface mixed layer) varied from 9.414.6 mol photons $\mathrm{m}^{-2} \mathrm{day}^{-1}$ at shelf-break sites to 4.617.3 mol photons $\mathrm{m}^{-2} \mathrm{day}^{-1}$ at stratified shelf sites, with 7.3-8.6 mol photons $\mathrm{m}^{-2} \mathrm{day}^{-1}$ at open ocean sites, and 3.0-3.3 mol photons $\mathrm{m}^{-2}$ day $^{-1}$ at fully mixed sites (Poulton et al., 2014).

The distribution of chlorophyll $a$ pigment (an indicator of overall phytoplankton abundance) in the study area during the month of June is shown in Fig. 4, and demonstrates the expected variability in biological conditions along the route.

\section{Main results in this special issue}

Five main bioassay experiments were carried out on the cruise, during each of which about eighty $4.5 \mathrm{~L}$ bottles were filled with seawater from the surface layer and subjected to four different $\mathrm{CO}_{2}$ levels (ambient, 550, 750 and $1000 \mu \mathrm{atm}$ ) through manipulation of the carbonate chemistry using bicarbonate and acid (Gattuso et al., 2010) before being sealed. After 48 and $96 \mathrm{~h}$, bottles were re-opened and the effects of the different $\mathrm{CO}_{2}$ levels were investigated. Three additional bioassay experiments were carried out in which both nutrients and $\mathrm{CO}_{2}$ were manipulated. For further details of the bioassay methods see the paper by Richier et al. (2014). These authors also report results on the effects of $\mathrm{CO}_{2}$ on phytoplankton community structure and carbon cycling. Statistically robust results were obtained (because of the high degree of replication), namely that higher $\mathrm{CO}_{2}$ levels inhibited the growth of small (less than $10 \mu \mathrm{m}$ in diameter) phytoplankton and led to larger carbonate chemistry changes by phytoplankton processes, as predicted by theory, due to a reduction in the buffer capacity.

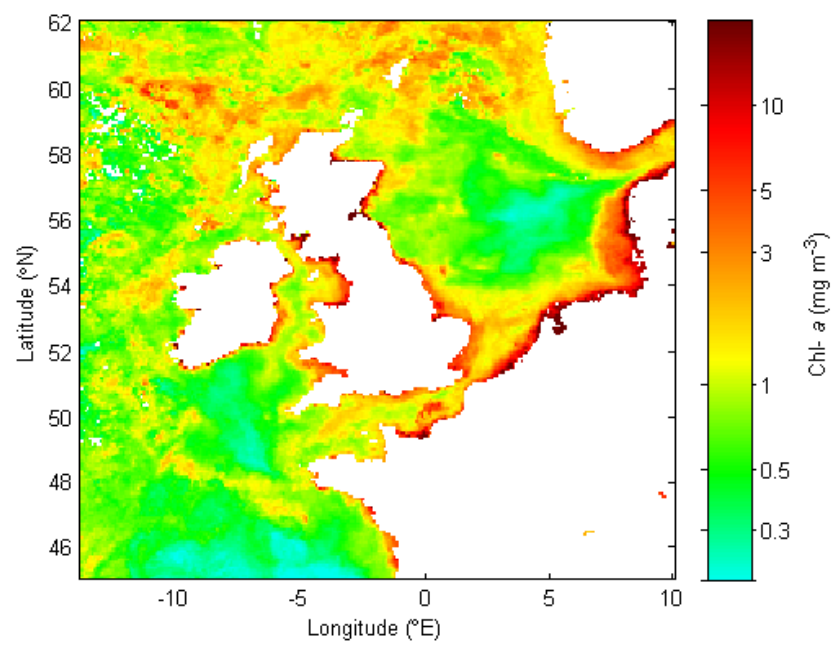

Figure 4. Aqua MODIS monthly composite satellite image of chlorophyll concentration across the study area in June 2011.

A major reason for concern over ocean acidification has been the theoretical prediction of strong ocean acidification impacts on calcifying organisms, including, among the plankton, coccolithophores. Several papers in the special issue focus on this phytoplankton group. Poulton et al. (2014) exploited the wide range of measurements made on the cruise, including calcification and primary production rates, environmental parameters, coccolithophore abundance and species diversity, to investigate the factors that controlled calcification rate in the bioassays and in situ in the environment. They observed a strong inhibitory effect of $750 \mu \mathrm{atm}$ $\mathrm{CO}_{2}$ on bulk calcification rate in two out of three bioassay experiments, with light and water column structure important in determining the rate of calcification per cell under field conditions. Krueger-Hadfield et al. (2014) examined the degree of genetic diversity within the coccolithophore species Emiliania huxleyi, and considered what it means for the prevalence of sexual versus asexual reproduction within blooms. Their findings challenge current understanding, suggesting that asexual reproduction is more important than previously suspected. A third paper on coccolithophores (Young et al., 2014) examined the effect of $\mathrm{CO}_{2}$ level on coccolithophore numbers and on coccolith morphology (coccolith shape and calcite content). Coccoliths are the calcium carbonate plates that coccolithophores synthesise and then place in a covering around the cell. In the single bioassay experiment where coccolithophores were most numerous and growing most rapidly, there was a strong difference between the different $\mathrm{CO}_{2}$ levels, with reduced coccolithophore growth seen in those experimental bottles at the highest $\mathrm{CO}_{2}$ level. No effect was seen on coccolithophore morphology. The abundance and assemblage composition of coccolithophores in the field did not appear to be controlled by the carbonate chemistry, with the major difference instead being between shelf and off-shelf communities. 
Ocean acidification could potentially alter the nature of marine carbon cycle if more dissolved organic carbon (DOC) and/or transparent exopolymeric particles (TEPs) are produced at high $\mathrm{CO}_{2}$, if ocean acidification causes a greater fraction of primary production to be ultimately channelled to the dissolved phase rather than particles, or if a greater production of "sticky" TEPs leads to increased flocculation and export (Czerny et al., 2013; Engel et al., 2002, 2004). An examination of DOC and TEP dynamics in the bioassay experiments (MacGilchrist et al., 2014) found no evidence of $\mathrm{CO}_{2}$ effects on DOC production, but clear indirect effects were observed on TEP production, attributed to the effect of $\mathrm{CO}_{2}$ on phytoplankton growth (Richier et al., 2014), although these were found to be dependent on the environmental setting. In one of the experiments, the variation of the TEP production was the result of a direct effect of $\mathrm{CO}_{2}$, as hypothesised by other studies, and linked to post-bloom conditions.

Two further papers also looked at processes relevant to climate impacts. Hopkins and Archer (2014) studied ocean acidification impacts on the dimethyl sulfide (DMS) and dimethyl sulfoniopropionate (DMSP) system, including measurements of rates as well as standing stocks. They found a consistent pattern of higher DMS and lower DMSP at high $\mathrm{CO}_{2}$ in the bioassays, a different response from that seen in previous mesocosm experiments. Clark et al. (2014) investigated effects on nitrogen cycling and $\mathrm{N}_{2} \mathrm{O}$ production, an area of concern for ocean acidification because it is known that a change in $\mathrm{pH}$ should lead to a change in the chemical balance between ammonium and ammonia. Despite this, no clear effect of ocean acidification on ammonium oxidation, nitrogen regeneration rates or $\mathrm{N}_{2} \mathrm{O}$ production could be discerned.

Acknowledgements. The work described here was carried out as part of the Surface Ocean Consortium of the United Kingdom Ocean Acidification (UKOA) research programme. We are grateful for funding of this research programme to the Natural Environment Research Council (NERC) of the United Kingdom; the UK government Department of the Environment, Food and Rural Affairs (DEFRA); and the UK government Department of Energy and Climate Change (DECC) (grant agreement NE/H017348/1 for the University of Southampton). We thank the officers and crew of the RRS Discovery D366 cruise. We are indebted to Phil Williamson for his excellent management of the research programme as a whole, and to Athena Drakou, Carol Turley and Kelvin Boot for outreach activities. We are also grateful to have benefitted from the efficient and enthusiastic organisation of consortium activities by Athena Drakou. Finally, we would like to express thanks to Jean-Pierre Gattuso for his considerable efforts in the guest editorship of this special issue.

\section{References}

Bange, H. W.: New directions: The importance of oceanic nitrous oxide emissions, Atmos. Environ., 40, 198-199, 2006.

Barcelos e Ramos, J., Biswas, H., Schulz, K. G., LaRoche, J., and Riebesell, U. (2007). Effect of rising atmospheric carbon dioxide on the marine nitrogen fixer Trichodesmium, Global Biogeochem. Cy., 21, GB2028, doi:10.1029/2006GB002898, 2007.

Caldeira, K. and Wickett, M. E.: Oceanography: anthropogenic carbon and ocean $\mathrm{pH}$, Nature, 425, 365-365, 2003.

Chen, C. T. A. and Borges, A. V.: Reconciling opposing views on carbon cycling in the coastal ocean: Continental shelves as sinks and near-shore ecosystems as sources of atmospheric $\mathrm{CO}_{2}$, Deep-Sea Res. Pt. II, 56, 578-590, 2009.

Clark, D. R., Brown, I. J., Rees, A. P., Somerfield, P. J., and Miller, P. I.: The influence of ocean acidification on nitrogen regeneration and nitrous oxide production in the northwest European shelf sea, Biogeosciences, 11, 4985-5005, doi:10.5194/bg-114985-2014, 2014.

Collins, S. and Bell, G.: Evolution of natural algal populations at elevated $\mathrm{CO}_{2}$, Ecol. Lett., 9, 129-135, 2006.

Czerny, J., Schulz, K. G., Boxhammer, T., Bellerby, R. G. J., Büdenbender, J., Engel, A., Krug, S. A., Ludwig, A., Nachtigall, K., Nondal, G., Niehoff, B., Silyakova, A., and Riebesell, U.: Implications of elevated $\mathrm{CO}_{2}$ on pelagic carbon fluxes in an Arctic mesocosm study - an elemental mass balance approach, Biogeosciences, 10, 3109-3125, doi:10.5194/bg-10-3109-2013, 2013.

Engel, A., Goldthwait, S., Passow, U., and Alldredge, A.: Temporal decoupling of carbon and nitrogen dynamics in a mesocosm diatom bloom, Limnol. Oceanogr., 47, 753-761, 2002.

Engel, A., Delille, B., Jacquet, S., Riebesell, U., Rochelle-Newall, E., Terbrüggen, A., and Zondervan, I.: Transparent exopolymer particles and dissolved organic carbon production by Emiliania huxleyi exposed to different $\mathrm{CO} 2$ concentrations: a mesocosm experiment, Aquat. Microb. Ecol., 34, 93-104, 2004.

Gattuso, J.-P., Gao, K., Lee, K., Rost, B., and Schulz, K. G.: Approaches and tools to manipulate the carbonate chemistry, in: Guide to best practices for ocean acidification research and data reporting, edited by: Riebesell, U., Fabry, V. J., Hansson, L., and Gattuso, J. P., Publications Office of the European Union, Luxembourg, 41-52, 2010.

Gattuso, J.-P., Brewer, P. G., Hoegh-Guldberg, O., Kleypas, J. A., Pörtner, H.-O., and Schmidt, D. N.: Cross-chapter box on ocean acidification, in: Climate Change 2014: Impacts, Adaptation, and Vulnerability. Part A: Global and Sectoral Aspects. Contribution of Working Group II to the Fifth Assessment Report of the Intergovernmental Panel on Climate Change, edited by: Field, C. B., Barros, V. R., Dokken, D. J., Mach, K. J., Mastrandrea, M. D., Bilir, T. E., Chatterjee, M., Ebi, K. L., Estrada, Y. O., Genova, R. C., Girma, B., Kissel, E. S., Levy, A. N., MacCracken, S., Mastrandrea, P. R., and White, L. L., Cambridge University Press, Cambridge, United Kingdom and New York, NY, USA, 129-131, 2014.

Hopkins, F. E. and Archer, S. D.: Consistent increase in dimethyl sulfide (DMS) in response to high $\mathrm{CO}_{2}$ in five shipboard bioassays from contrasting NW European waters, Biogeosciences, 11, 4925-4940, doi:10.5194/bg-11-4925-2014, 2014.

Hutchins, D. A., Fu, F. X., Zhang, Y., Warner, M. E., Feng, Y., Portune, K., and Mulholland, M. R.: $\mathrm{CO}_{2}$ control of Trichodesmium N2 fixation, photosynthesis, growth rates, and 
elemental ratios: Implications for past, present, and future ocean biogeochemistry, Limnol. Oceanogr., 52, 1293-1304, doi:10.4319/lo.2007.52.4.1293, 2007.

Kranz, S., Sültemeyer, D., Richter, K. U., and Rost, B.: Carbon acquisition in Trichodesmium: The effect of $p \mathrm{CO}_{2}$ and diurnal changes, Limnol. Oceanogr., 54, 548-559, 2009.

Krueger-Hadfield, S. A., Balestreri, C., Schroeder, J., Highfield, A., Helaouët, P., Allum, J., Moate, R., Lohbeck, K. T., Miller, P. I., Riebesell, U., Reusch, T. B. H., Rickaby, R. E. M., Young, J., Hallegraeff, G., Brownlee, C., and Schroeder, D. C.: Genotyping an Emiliania huxleyi (prymnesiophyceae) bloom event in the North Sea reveals evidence of asexual reproduction, Biogeosciences, 11, 5215-5234, doi:10.5194/bg-11-5215-2014, 2014.

Law, C. S., Breitbarth, E., Hoffmann, L. J., McGraw, C. M., Langlois, R. J., LaRoche, J., and Safi, K. A.: No stimulation of nitrogen fixation by non-filamentous diazotrophs under elevated $\mathrm{CO}_{2}$ in the South Pacific, Glob. Change Biol., 18, 3004-3014, 2012.

Leggett, J., Pepper, W. J., Swart, R. J., Edmonds, J., Meira Filho, L. G., Mintzer, I., and Wang, M. X.: Emissions scenarios for the IPCC: an update, Climate Change, 71-95, 1992.

Levitan, O., Rosenberg, G., Setlik, I., Setlikova, E., Grigel, J., Klepetar, J., and Berman-Frank, I.: Elevated $\mathrm{CO}_{2}$ enhances nitrogen fixation and growth in the marine cyanobacterium Trichodesmium, Glob. Change Biol., 13, 531-538, 2007.

Lohbeck, K. T., Riebesell, U., and Reusch, T. B.: Adaptive evolution of a key phytoplankton species to ocean acidification, Nat. Geosci., 5, 346-351, 2012.

Lomas, M. W., Hopkinson, B. M., Losh, J. L., Ryan, D. E., Shi, D. L., Xu, Y., and Morel, F. M. M.: Effect of ocean acidification on cyanobacteria in the subtropical North Atlantic, Aquat. Microb. Ecol., 66, 211-222, 2012.

MacGilchrist, G. A., Shi, T., Tyrrell, T., Richier, S., Moore, C. M., Dumousseaud, C., and Achterberg, E. P.: Effect of enhanced $p \mathrm{CO}_{2}$ levels on the production of dissolved organic carbon and transparent exopolymer particles in short-term bioassay experiments, Biogeosciences, 11, 3695-3706, doi:10.5194/bg-113695-2014, 2014.

Pauly, D., Christensen, V., Guénette, S., Pitcher, T. J., Sumaila, U. R., Walters, C. J., and Zeller, D.: Towards sustainability in world fisheries, Nature, 418, 689-695, 2002.

Pingree, R. D. and Griffiths, D. K.: Tidal fronts on the shelf seas around the British Isles, J. Geophys. Res., 83, 4615-4622, 1978.
Poulton, A. J., Stinchcombe, M. C., Achterberg, E. P., Bakker, D. C. E., Dumousseaud, C., Lawson, H. E., Lee, G. A., Richier, S., Suggett, D. J., and Young, J. R.: Coccolithophores on the north-west European shelf: calcification rates and environmental controls, Biogeosciences, 11, 3919-3940, doi:10.5194/bg-113919-2014, 2014.

Ribas-Ribas, M., Rérolle, V. M. C., Bakker, D. C. E., Kitidis, V., Lee, G. A., Brown, I., Achterberg, E. P., Hardman-Mountford, N. J., and Tyrrell, T.: Intercomparison of carbonate chemistry measurements on a cruise in northwestern European shelf seas, Biogeosciences, 11, 4339-4355, doi:10.5194/bg-11-4339-2014, 2014.

Richier, S., Achterberg, E. P., Dumousseaud, C., Poulton, A. J., Suggett, D. J., Tyrrell, T., Zubkov, M. V., and Moore, C. M.: Phytoplankton responses and associated carbon cycling during shipboard carbonate chemistry manipulation experiments conducted around Northwest European shelf seas, Biogeosciences, 11, 4733-4752, doi:10.5194/bg-11-4733-2014, 2014.

Riebesell, U., Lee, K., and Nejstgaard, J. C.: Pelagic mesocosms, in: Guide to best practices for ocean acidification research and data reporting, edited by: Riebesell, U., Fabry, V. J., Hansson, L., and Gattuso, J. P., Publications Office of the European Union, Luxembourg, 41-52, 2010.

Shi, D., Kranz, S. A., Kim, J. M., and Morel, F. M.: Ocean acidification slows nitrogen fixation and growth in the dominant diazotroph Trichodesmium under low-iron conditions, P. Natl. Acad. Sci., 109, E3094-E3100, doi:10.1073/pnas.1216012109, 2012.

Simpson, J. H. and Sharples, J.: Introduction to the physical and biological oceanography of shelf seas, Cambridge University Press, Cambridge, UK, 2012.

Tatters, A. O., Roleda, M. Y., Schnetzer, A., Fu, F., Hurd, C. L., Boyd, P. W., Caron, D. A., Lie, A. A. Y., Hoffmann, L. J., and Hutchins, D. A.: Short-and long-term conditioning of a temperate marine diatom community to acidification and warming, Philos. T. R. Soc. B, 368, 20120437, doi:10.1098/rstb.2012.0437, 2013.

Thomas, H., Bozec, Y., Elkalay, K., and De Baar, H. J.: Enhanced open ocean storage of $\mathrm{CO}_{2}$ from shelf sea pumping, Science, 304, 1005-1008, 2004.

Young, J. R., Poulton, A. J., and Tyrrell, T.: Morphology of Emiliania huxleyi coccoliths on the northwestern European shelf - is there an influence of carbonate chemistry?, Biogeosciences, 11, 4771-4782, doi:10.5194/bg-11-4771-2014, 2014. 